\title{
尋常性天疮瘡の口腔症状に関する検討
}

\author{
赤坂庸子・神部芳 則*・古谷野浩美・野口忠秀
}

\section{Clinical study on oral findings of pemphigus vulgaris}

\author{
Yoko Akasaka • Yoshinori Jinbu* • Hiromi Koyano \\ Tadahide NoGuchI
}

\begin{abstract}
Pemphigus vulgaris is accompanied by oral erosions in the overwhelming majority of cases. The authors studied oral findings at the first visit of 12 patients with pemphigus vulgaris.

1. In 9 cases, the chief complaint was pain of the gingiva and/or oral mucosa. In 2 cases, it was erosion of the oral mucosa, and in 1 case it was oral bleeding.

2. In 11 cases, erosion was observed in several regions of the oral cavity.

3. Erosion was frequently observed on the buccal mucosa, gingiva and hard palate. However, erosion of the alveolar mucosa and tongue was rare.

These results suggest that the characteristics of erosion differ depending on the region of the oral cavity which is affected.
\end{abstract}

Key words: pemphigus vulgaris (尋常性天疱瘔), oral findings (口腔症状), initial lesion（初 発部位)

\section{緒言}

天疮瘡は皮虞および粘膜に棘融解性水疮を生じる自己 免疫性水疮症であり, 中でも尋常性天疮瘡は発生頻度が 高く，そのほとんどの症例で口腔内に症状が現れる11. われわれは, 口腔粘膜に扣ける水疱形成のメカニズムを あきらかにするために, 口腔粘膜上皮と皮膚の培養細胞 を用いて基礎的研究を重ね， 口腔粘膜上皮と皮膚の細胞 では天疮瘡血清に対する反応様式が異なること，また， 口腔粘膜上皮でも部位によって反応様式に違いのあるこ とを示した 2〜5).

そこでわれわれは, 尋常性天疮瘡患者の口腔症状とそ の好発部位について検討し,すでに報告した基礎研究の

自治医科大学歯科口腔外科学教窒

（主任：赤坂庸子教授）

* 神奈川歯科大学放射線学教室

（主任：鹿島 勇教授）

Department of Dentistry and Oral Surgery Jichi Medical School (Chief: Prof. Yoko Akasaka)

* Department of Oral and Maxillofacial Radiology Kanagawa Dental College (Chief: Prof. Isamu Kashima)

受付日：平成 5 年 2 月 9 日

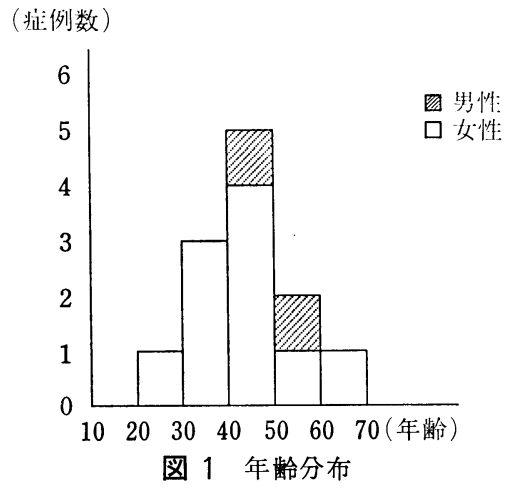

結果と, 臨床症状との関連について考察を加えたので報 告する.

\section{対象なびらに研究方法}

自治医科大学附属病院歯科口腔外科を受診し, 尋常性 天疮瘡と確定診断された12例（男性 2 例，女性10例）を 対象とし, 初診時の口腔症状について検討した。

結果

対象症例の平均年齢は 44.2 歳で, 年齢分布は 40 歳代が 
表 1 対象症例

\begin{tabular}{|c|c|c|c|c|c|c|c|c|c|c|c|c|}
\hline \multirow{2}{*}{$\begin{array}{l}\text { 症例 } \\
\text { No. }\end{array}$} & \multirow{2}{*}{ 年龄 } & \multirow{2}{*}{ 性別 } & \multirow{2}{*}{ 主訴 } & \multicolumn{9}{|c|}{ 症状の認められた部位 } \\
\hline & & & & 軟口蓋 & 硬口蓋 & 歯 & 雬槽粘膜 & 頓粘膜 & 舌 & 口底粘膜 & 口 & 皮 廉 \\
\hline 1 & 48 & F & 痛み & & 0 & & & 0 & & 0 & & 0 \\
\hline 2 & 66 & F & 痛み & & 0 & 0 & & O & & 0 & & 0 \\
\hline 3 & 55 & M & 痛み & 0 & & & & 0 & & 0 & 0 & \\
\hline 4 & 28 & F & 出血 & 0 & O & 0 & & & & & & \\
\hline 5 & 35 & F & 痛み & & 0 & & & O & O & & O & \\
\hline 6 & 57 & F & 痛み & 0 & O & & & 0 & & & & \\
\hline 7 & 34 & F & 痛み & 0 & & O & & O & O & O & 0 & 0 \\
\hline 8 & 30 & F & 痛み & & & 0 & & & & & & 0 \\
\hline 9 & 48 & $\mathrm{~F}$ & 痛み & 0 & & 0 & & 0 & & 0 & & \\
\hline 10 & 48 & $\mathrm{~F}$ & 荒れ & & O & 0 & & & & & O & 0 \\
\hline 11 & 41 & $\mathbf{M}$ & 痛み & & & O & & 0 & & & & \\
\hline 12 & 40 & F & 荒れ & & & 0 & 0 & O & & & & \\
\hline
\end{tabular}

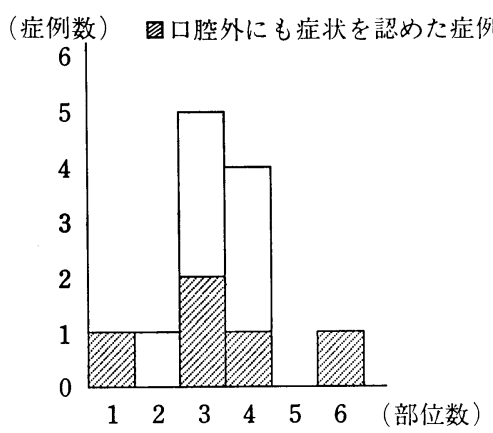

図 2 口腔症状の部位数別頻度

5 例 $(42 \%)$ で最も多く, 次いで30歳代が 3 例, 50 歳代 が 2 例であった（表 1 , 図1）。最年少は 28 歳で最高年 秢は 66 歳であった。性差については, 男 : 女 =1:5 で 女性が多かった。

主訴については，歯肉，口腔粘膜の痛みが 9 例(75\%) で最も多く, 口腔内の荒れ, びらんが 2 例, 口腔内の出 血が 1 例であった（表 1 ）.

口腔症状は 1 例で口唇に水疱が観察されたが，その他 はすべての症例で発赤の強いびらん状態を呈し, 症例に よっては, 剝離した上皮の残存を認めたものの，水疱は 観察されなかった。

口腔を軟口蓋, 硬口蓋, 歯肉, 歯槽粘膜, 煩粘膜, 舌, 口底粘膜, 口唇の 8 部位に分けて症状のみられた部 位を検討した。症状のみられた部位数は 3 部位が 5 例 $(42 \%) ， 4$ 部位が 4 例 (33\%)，1 部位， 2 部位， 6 部位 がそれぞれ 1 例ずつであった（図 2)，12例中 11 例（92 \%) で複数の部位に症状が認められ, 平均 3.3 部位に症 状を認めた，部位別にみると，頓粘膜が 9 例 (75\%) で

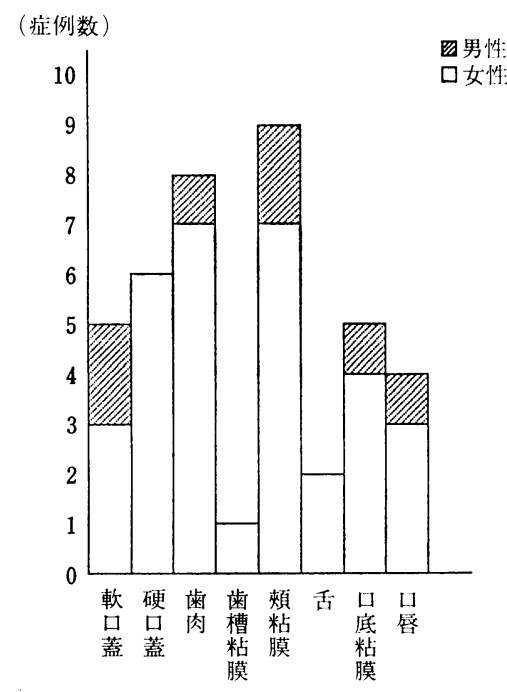

図 3 口腔症状の部位別頻度

最も多く, 次いで歯肉 8 例, 硬口蓋 6 例の順であった. 一方, 歯槽粘膜は 1 例, 舌は 2 例で最も少ない結果であ った（図了）。ただし，舌については症状のみられたの は舌縁部, 舌下面であり, 舌背に生じた症例はなかっ た．部位別の組合せでは，その頻度からもあきらかなよ らに, 頓粘膜, 口蓋, 歯肉の組合せが多かった。一方, 12例中口腔以外にも症状を認めたのは 5 例 (42\%) であ り，他の 7 例では症状は口腔内に限局していた。 口腔以 外に症状を認めた 5 例はすべて女性で，上腕部，前胸 部，背部，大腿部の皮膚，および 外陰部に 症状を認め た。腔以外にも症状を認めた症例については, 症例数 も少なく，部位数や年龄，口腔内の部位との間に一定の 
傾向はみられなかった。

\section{考察}

尋常性天疮瘡は，そのほとんどの症例で口腔に症状が 生じる1)。しかし口腔粘膜に水疱が発生しやすい理由や 口腔粘膜に打ける水疮形成のメカニズムは不明である. われわれはケラチン中間線維とデスモゾームの分布状態 を指標にして，口腔粘膜上皮と表皮細胞では天疱瘡血清 に対する細胞の反応様式に違いのあること，また口腔粘 膜上皮細胞でも，部位によって天疮瘡血清に対する反応 様式に違いのあることを示した ${ }^{2 \sim 5)}$. そこで，われわれ が示したよらな基礎研究の結果が, 実際に臨床症状を反 映しているかどらかを検討する目的で本研究を行った。

今回対象とした尋常性天疮瘡と確定した12症例はすべ てロ腔内に症状を認めた。性差については，女性の割合 がやや高い傾向がみられたが，年齢分布については従来 の報告とほぼ一致していた

主訴については, 歯肉, 口腔粘膜の痛みが最も多く, 尋常性天疮瘡の患者が歯科, 口腔外科を最初に受診する

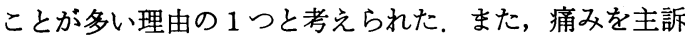
にした症例は頉粘膜，口蓋にびらんを認めた 症例が 多 く,これらの部位は食物による物理的, 化学的刺激を受 けやすい部位でもあり,このことが痛みの発生に関係し ていると思われた。腔症状の好発部位について Lamey $ら^{6)}$ は，尋常性天疮瘡患者 30 例について分析し， 1 例を 除き複数の部位に症状がみられたこと，軟口蓋が $80 \%$ て 最も多く，次いで煩粘膜が $46 \%$ であったのに対し，乱 舌下面と舌面を合わせて $20 \%$ ， 口唇は $10 \%$ と少なかった ことを報告している。一方，Zegarelli ら〕は，尋常性天 疱瘡患者28例について具体的に数字では示していないが 頓粘膜, 口蓋, 歯肉に症状が多く, 舌, 口底粘膜, 口 唇は少なかったことを報告している。 Zegarelli ら7), Pisanti ら ${ }^{8)}$ は天疮瘡の発症は人種により大きな差がある ことを報告しているが， Lamey $ら^{6)}$, Zegarelli ら 報告は扮扮むねわれわれの結果に一致している。このよ らに口腔内では, 症状の現れやすい部位と現れ難い部位 のあることが示された。そして, この結果は，すでにわ れわれが示した細胞レベルでの天疮瘡血清に対する反応 性の違いを反映していると考えられた。このような細胞 による反応性の違いの原因については，上皮細胞のヶラ チン分子の発現状態の違い もつ, 細胞膜構成成分の違い5)などが考兄られる，今後 われわれは, 口腔粘膜に打ける水疮形成のメカニズムに
ついて，さらに詳細に研究を進めていく予定である。

\section{結語}

尋常性天疱㾑と確定䛦断された12例について, 口腔症 状拈よび症状の現れた部位を検討した。 その結果,

1. 主訴は歯肉, 口腔粘膜の痛みが 9 例で最も多く, 次いで口腔内の荒れ，びらんが 2 例であった。

2. 12例中11例で複数の部位に症状が確認された。

3. 部位別では煩粘膜が 9 例で最も多く, 歯肉 8 例, 硬 口蓋 6 例で, 歯槽粘膜, 乱少なかった.

部位別による症状の現れ方の違いについては，われわ れが報告してきた細胞レベルに和ける基礎研究を反映し ているものと思われた。

\section{引用 文 献}

1）矢尾板英夫：水疮症（特集：皮虙疾患の病理䛌 断）病理々臨床 2: 607-617 1984.

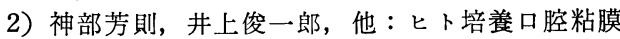

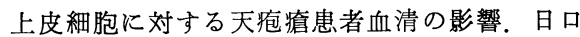
外誌 34: 2091-2095 1988.

3）神部芳則, 北島康雄, 他：七ト歯肉部培養上皮 細胞のケラチン中間線維扰よびデスモゾームの 分布に対する天疮殓患者血清の影響。日口外誌 35: 390-395 1989.

4）神部芳則, 赤坂庸子, 他：七ト茵肉部培養上皮 細胞汶対する天疮癜患者血清の影響。日口外誌 38: 11-14 1992.

5) Jinbu, Y., Kitajima, Y., et al.: Different effects of pemphigus antibody and plasmin on the distribution of keratin intermediate filaments and desmoplakins between cultured oral and epidermal keratinocytes. J Dermatol Sci 3: 6-12 1992.

6) Lamey, P-J., Rees, T.D., et al.: Oral presentation of pemphigus vulgaris and its response to systemic steroid therapy. OS OM OP 74: 54-57 1992.

7) Zegarelli, D.J. and Zegarelli, E.V.: Intraoral pemphigus vulgaris. OS OM OP 44: 3843931977.

8) Pisanti, S., Sharer, Y., et al.: Pemphigus vulgaris: incidence in Jews of different ethnic groups sccording to age, sex and initial lesion. OS OM OP 38: 382-387 1974.

9）神部芳則, 井上俊一郎, 他: 七上歯肉部培養上 皮細胞に批ける細胞骨格の分布。日口外誌 34 : 1055-1060 1988. 